\title{
The decline of the endemic Fijian crested iguana Brachylophus vitiensis in the Yasawa and Mamanuca archipelagos, western Fiji
}

\author{
Peter S. Harlow, Martin Fisher, Marika Tuiwawa, Pita N. Biciloa, Jorge M. Palmeirim, Charlene Mersai, \\ Shivanjani Naidu, Alifereti Naikatini, Baravi Thaman, Jone Niukula and Erica Strand
}

\begin{abstract}
The endemic Fijian crested iguana Brachylophus vitiensis, categorized as Critically Endangered on the IUCN Red List, has been recorded from several islands in western Fiji. We conducted a survey for the crested iguana on 12 uninhabited and five inhabited islands in the Yasawa and Mamanuca archipelagos of western Fiji in September 2000. Night searches for sleeping iguanas along a total of $11.2 \mathrm{~km}$ of forest transects suggest that crested iguanas are either extremely rare or extinct on all of these islands. Although we collectively searched a total of $44 \mathrm{~km}$ of transect over 123 person hours, we located crested iguanas on only four islands: three small uninhabited islands (all $<73 \mathrm{ha}$ ) and one large inhabited island $(22 \mathrm{~km})$. In July 2003 we resurveyed two islands identified as having the best
\end{abstract}

potential for the long-term conservation of crested iguanas, and found that populations were continuing to decline. We suggest that the scarcity of crested iguanas on all islands surveyed is due to the combination of habitat loss and the introduction of exotic predators. All islands surveyed have free ranging goats, forest fires have occurred repeatedly over the last few decades, and feral cats are established on many islands. To reverse the population decline of this species immediate intervention is required on selected islands to halt continuing forest degradation and to clarify the effects of introduced predators.

Keywords Brachylophus vitiensis, crested iguana, Fiji islands, forest degradation, Pacific, transect survey.

\section{Introduction}

In 1981 the Fijian crested iguana Brachylophus vitiensis was described from a single population found on the small uninhabited island of Yadua Taba (Gibbons, 1981). Even before the species description was published the island was declared Fiji's first wildlife sanctuary

Peter Harlow $^{\dagger}$ (Corresponding author) School of Biological Sciences, Macquarie University, NSW 2109, Australia. E-mail pharlow@zoo.nsw.gov.au

Martin Fisher ${ }^{2}$, Charlene Mersai, Shivanjani Naidu, Alifereti Naikatini and Baravi Thaman Department of Biological Sciences, University of the South Pacific, PO Box 1168 Suva, Fiji.

Marika Tuiwawa South Pacific Regional Herbarium, University of the South Pacific, PO Box 1168 Suva, Fiji.

Pita N. Biciloa and Jone Niukula National Trust of Fiji Islands, PO Box 2089, Government Buildings, Suva, Fiji.

Jorge M. Palmeirim Department of Animal Biology, Faculdade de Ciencias, Universidade de Lisboa, 1749-016 Lisboa, Portugal.

Erica Strand 790 Dixon Way, Los Altos CA94022, USA

${ }^{1}$ Current address: Herpetofauna Division, Taronga Zoo, PO Box 20, Mosman, NSW 2088, Australia.

${ }^{2}$ Current address: Fauna \& Flora International, Great Eastern House, Tenison Road, Cambridge, CB1 2TT, UK

Received 14 December 2005. Revision requested 8 June 2006. Accepted 3 August 2006.
(Gibbons, 1984a). Prior to this discovery only a single species of iguana, the smaller banded iguana Brachylophus fasciatus, was known from the South Pacific (Brongniart, 1800). The banded iguana is widely distributed and is recorded from 34 Fijian islands (Zug, 1991), also occurs on Tonga (Gibbons \& Watkins, 1982) and has been introduced to Vanuatu (Bauer, 1988).

The Yasawa and Mamanuca island groups of Fiji form a $150 \mathrm{~km}$ long arc north-west of the main Fijian island of Viti Levu (Fig. 1). Gibbons visited the Yasawa and Mamanuca groups in 1982 and reported that crested iguanas occurred on at least eight islands (Gibbons, $1984 a, b, 1985 a, b)$ but were seldom seen on any islands except for the island of Monuriki in the Mamanuca archipelago, where sightings were still frequent (Gibbons, 1984a).

Since Gibbons visited these islands there have been only occasional anecdotal reports of crested iguana. In April 1990 an international team attempted to survey the terrestrial vertebrates of the Yasawa and Mamanuca archipelagos, and briefly visited many of these same islands. Although the main objective of their survey was to document the distribution of the crested iguana, none were seen except for a small captive group on the tourist resort island of Nanuya Levu (Shea, 1995; G.M. Shea, pers. comm.). PSH and PNB visited the island of Monuriki in the Mamanucas in 1998 and used transect 


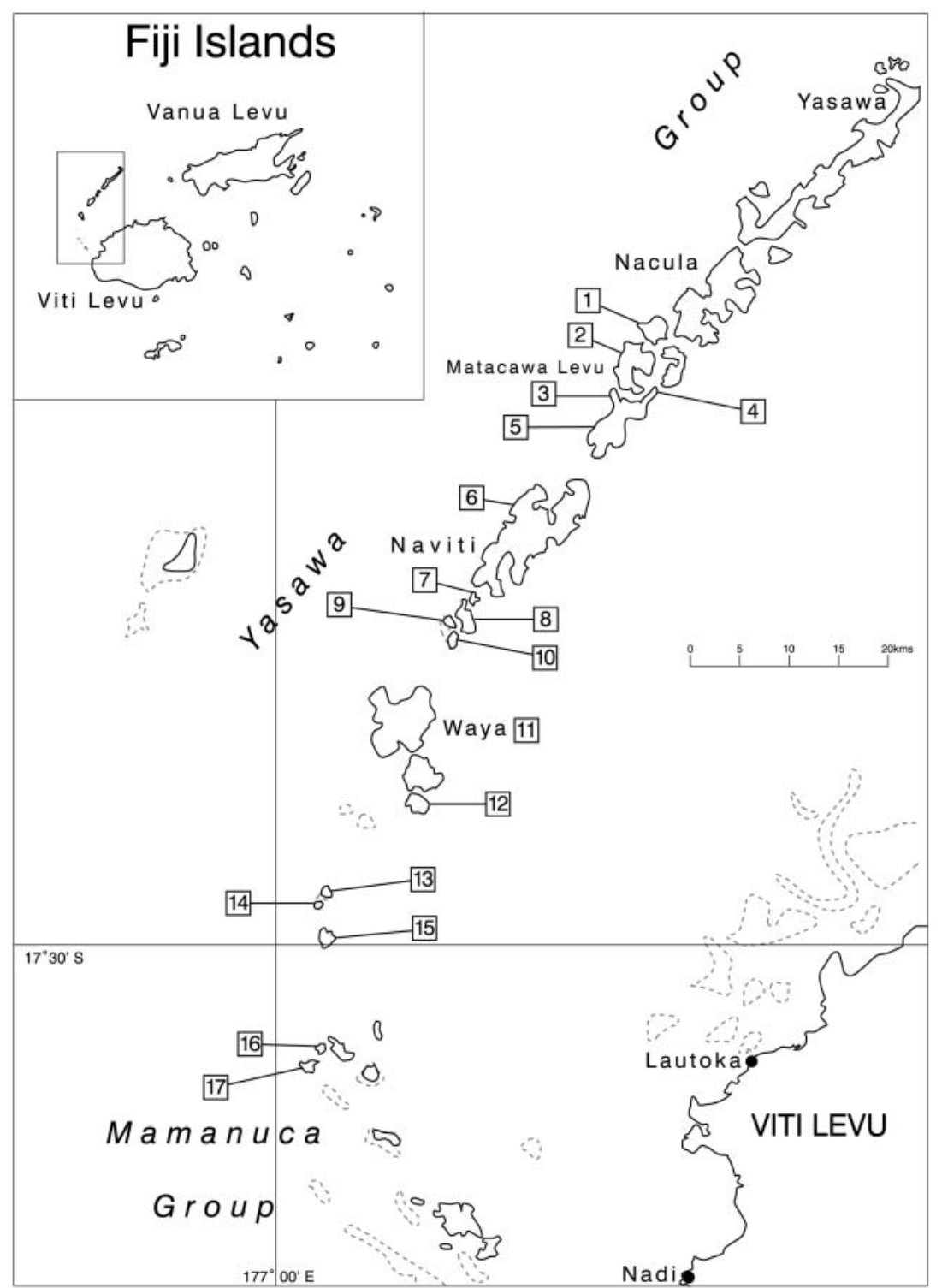

Fig. 1 The Yasawa and Mamanuca archipelagos, with the 17 surveyed islands (see Table 1 for details of the islands). 1, Tavewa; 2, Matacawa Levu; 3, Deviulau; 4, Kubulau; 5, Yaqeta; 6, Naviti; 7, Drawaqa; 8, Nanuya Balavu; 9, Naukacuvu; 10, Narara; 11, Waya; 12, Kuata; 13, Navadra; 14, Vanua Levu; 15, Kadomo; 16, Monu; 17, Monuriki. The inset shows the location of the two archipelagos in western Fiji.

surveys to estimate the crested iguana population (Harlow \& Biciloa, 2001). Their population estimate for the entire island, based on a total of 13 adult iguana sightings, was 40-80 individuals.

The Critically Endangered crested iguana (IUCN, 2006) is an arboreal herbivorous species restricted to islands with stands of dry or littoral forest, Fiji's most critically endangered habitat (Laurie et al., 1987). This distinctive forest type exists only on the leeward dry islands of Fiji, and on most of these islands has been burnt and cleared to make way for coconut plantations, gardens, grasslands for goat grazing or tourist resorts. In addition, on many of these islands the exotic vaivai tree Leucaena leucocephala has been introduced for goat feed, and forms impenetrable thickets that continue to expand into the remaining dry forests. Isolated dry forest remnants remain on many islands in the Yasawa and Mamanuca archipelagos, usually surviving on steep or rocky terrain and often surrounded by grasslands or vaivai thickets.

Here we report on the results of our crested iguana surveys in the Yasawa and Mamanuca archipelagos in September 2000, and follow-up surveys on two islands in July 2003. Our aims were to investigate the current status of crested iguanas on islands where Gibbons previously recorded them, and to identify islands with 
Table 1 The 17 islands surveyed for crested iguanas in September 2000, listed from north to south (Fig. 1). Monu and Monuriki were resurveyed in July 2003. Islands 1-12 are in the Yasawa archipelago, and 13-17 are in the Mamanuca archipelago. The five islands in bold are inhabited, and all others are uninhabited. Total survey time is the total person-hours of night transect searches. The iguana recorded on Deviulau was seen during daytime vegetation surveys, and not during night transect searches.

\begin{tabular}{|c|c|c|c|c|c|}
\hline Island name & $\begin{array}{l}\text { Total area } \\
\left(\mathrm{km}^{2}\right)\end{array}$ & $\begin{array}{l}\text { Maximum } \\
\text { altitude }(\mathrm{m})\end{array}$ & $\begin{array}{l}\text { Total survey time, } \\
\text { hours:minutes (no. of } \\
\text { transects) }\end{array}$ & $\begin{array}{l}\text { Total transect length, } \\
\text { m (no. of observers) }\end{array}$ & $\begin{array}{l}\text { No. of } \\
\text { iguanas seen }\end{array}$ \\
\hline 1. Tavewa & 1.62 & 180 & $10: 54(2)$ & $514(10)$ & 0 \\
\hline 2. Matacawa Levu & 9.5 & 300 & $11: 20(2)$ & $635(9)$ & 0 \\
\hline 3. Deviulau & 0.23 & 90 & $12: 20(2)$ & $571(8)$ & 1 \\
\hline 4. Kubulau & 0.20 & 45 & $3: 20(1)$ & $251(4)$ & 0 \\
\hline 5. Yaqeta & 12.5 & 158 & $5: 0(2)$ & $599(6)$ & 0 \\
\hline 6. Naviti & 36.0 & 246 & 5:0 (1) & $523(3)$ & 0 \\
\hline 7. Drawaqa & 0.68 & 90 & $6: 0(1)$ & $525(6)$ & 0 \\
\hline 8. Nanuya Balavu & 0.80 & 120 & 6:30 (2) & $723(6)$ & 0 \\
\hline 9. Naukacuvu & 0.49 & 90 & 3:30 (1) & $531(3)$ & 0 \\
\hline 10. Narara & 0.50 & 90 & 6:40 (2) & $617(2)$ & 0 \\
\hline 11. Waya & 22 & 571 & $15: 20(5)$ & $1,266(15)$ & 2 \\
\hline 12. Kuata & 1.46 & 174 & $8: 50(3)$ & $981(9)$ & 0 \\
\hline 13. Navadra & 0.30 & 128 & $5: 30(1)$ & $573(5)$ & 0 \\
\hline 14. Vanua Levu & 0.51 & 107 & 3:50 (1) & $543(4)$ & 0 \\
\hline 15. Kadomo & 0.30 & 101 & $4: 40(2)$ & $660(5)$ & 0 \\
\hline 16. Monu & 0.73 & 216 & 6:15 (2) & $504(5)$ & 1 \\
\hline 17. Monuriki & 0.40 & 178 & 7:44 (1) & $922(5)$ & 2 \\
\hline 16. Monu (July 2003) & & & $45: 40(4)$ & $3,381(4)$ & 5 \\
\hline 17. Monuriki (July 2003) & & & 28:0 (4) & $2,327(4)$ & 8 \\
\hline
\end{tabular}

viable populations of crested iguanas suitable for protection and consideration for wildlife sanctuaries.

\section{Methods}

Most of the land in Fiji is owned by traditional clans of indigenous Fijians known as Mataqali. Each Mataqali typically consists of several dozen families, and tradition dictates that approval and permission must always be obtained before visiting Mataqali owned land. For all islands that we surveyed we first obtained permission from the elected head, the Turaga ni Mataqali (or his representative), before landing.

\section{Crested iguana surveys}

Iguana surveys were always conducted at night, when the well camouflaged crested iguanas are more visible against the dark forest background than during the day (Laurie et al., 1987; Harlow \& Biciloa, 2001). On each island surveyed a transect line of white cotton string was laid out during the day. The area to be surveyed was first traversed on foot, and transects were purposely placed through areas within dry forest remnants that appeared to have the maximum number and diversity of iguana food tree species. On many of the islands we surveyed dry forest remnants were restricted to steep valleys and rocky slopes, and the iguana food tree species were abundant only along ephemeral watercourses. The subjective location of our transect lines meant that our survey results are biased towards maximizing our chances of locating iguanas, and are thus not suitable for estimating average abundance within a particular forest remnant. All transect lines were laid by $\mathrm{PSH}$ and PNB, who have the most experience in recognizing crested iguanas food tree species.

Teams of between 2-7 (mean 4) observers using powerful head-mounted spotlights walked slowly along the transect line at night, searching all trees and shrubs directly above and on both sides of the transect line for sleeping iguanas. Dry forest remnants on 17 islands were surveyed for iguanas on 14 nights during 12-30 September 2000. September is the end of the dry season in Fiji, and both forest canopy cover and undergrowth are at their annual minimum density. Visibility within the forest canopy is thus at its annual maximum.

In 2003 four of us (PSH, PNB, JN \& ES) carried out more intensive surveys of Monuriki (3-5 July) and Monu islands (7-10 July). On Monuriki we searched the same transect as previously surveyed by Harlow \& Biciloa (2001) in 1998 and in September 2000, in addition to three new areas of potential habitat. These two islands were selected for more intensive survey as they have the best potential for the long term conservation of crested iguanas, being uninhabited, with scattered forest 
remnants and no evidence of feral cats. Both islands continue, however, to be subjected to forest degradation by intensive goat grazing and occasional forest fires.

\section{Vegetation surveys}

On 10 islands dry forest vegetation surveys were also conducted in September 2000. Because the vegetation immediately behind the beach or rocky foreshore is usually different from the vegetation further inland, vegetation surveys were always conducted $>50 \mathrm{~m}$ from the coast. At $50 \mathrm{~m}$ intervals along the transect line 10 * $10 \mathrm{~m}$ quadrats were measured and marked off with string, alternatively to the left or right side of the transect line, with the transect line forming one edge of the quadrat. All live trees $>2 \mathrm{~m}$ in height in each quadrat were identified and the diameter at breast height measured and recorded. Tree diameters were recorded to facilitate comparisons between trees of different size. Trees such as the beach hibiscus Hibiscus tiliaceus produce multiple shoots from prostrate stems (extensive underground root systems), making the identification of a single tree impossible. Large forest trees such as the moivi Kingiodendron platycarpum grow as single trees, and are easily identifiable as such.

In assessing the presence of iguana food tree species we added a further three species to the four identified by Gibbons (1984a) based on data for crested iguanas on Yadua Taba (P.S. Harlow \& P.N. Biciloa, unpubl. data), For the 523 iguanas recorded at night during May and October 1999, 77\% were sleeping in these seven tree species. As well as directly observing iguanas feeding in these species, we identified leaves, buds, flowers and/or fruit from these trees in the droppings of 56 captured (and released) crested iguanas.

\section{Feral animal surveys}

Goats were free ranging on all islands surveyed, but we did not estimate numbers. Sightings of cats, and occasionally dogs, during night time iguana surveys were recorded. Twenty-six collapsible aluminium Elliott live-traps were set on five islands in September 2000 to identify the species of rat present. Traps were baited with Cabin Crackers (a locally available, wheat based cracker biscuit) in the late afternoon, and checked at dawn the next day.

\section{Results}

On the 17 surveyed islands (Fig. 1) 31 transects were searched for a total of 123 person hours in 2000. Transects varied in length from 154 to $922 \mathrm{~m}$, and totalled $11.2 \mathrm{~km}$ (Table 1). Although we used standard line transect survey techniques (Buckland et al., 2001), because of the low numbers of iguanas we recorded we could not make abundance estimates. Crested iguanas were located on only four of the 17 islands: three small uninhabited islands (Deviulau, Monu and Monuriki; Plate 1) and one large, inhabited island (Waya). Six live crested iguanas were seen on these four islands: two on Monuriki and Waya, and one each on Deviulau and Monu. A freshly killed juvenile iguana was also found on Deviulau; it had been partially eaten, probably by a feral cat. In July 2003 our more intensive searches of Monuriki and Monu islands recorded 8 and 5 iguanas respectively (Table 1). On Monuriki four pairs of adult iguanas were located on $2.3 \mathrm{~km}$ of transect, while on Monu four adults and one subadult were located on 3.4 $\mathrm{km}$ of transect. Table 2 shows the survey effort and total number of crested iguanas recorded on Monuriki in three trips from 1998 to 2003.

Tree species abundance and diversity and the percentage of edible tree species present varied considerably between islands (Table 3 ) but the relative occurrence of iguana food tree species appeared to be a poor predictor of the presence or absence of crested iguanas. Free ranging goats were common on all surveyed islands, and all inhabited islands that we visited had semi-domestic and feral cats, as well as dogs. On the uninhabited island of Naukacuvu a cat was seen, and local villagers told us that cats have been

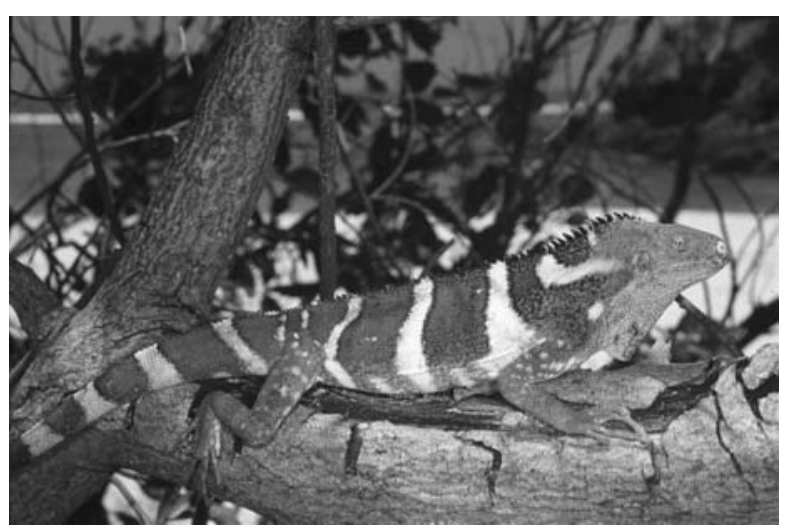

Plate 1 Fijian crested iguana on Monuriki (number 17 in Fig. 1).

Table 2 Results from three crested iguana surveys on Monuriki (labelled 17 on Fig. 1). The 1998 data are from Harlow \& Biciloa (2001).

\begin{tabular}{lllll}
\hline & $\begin{array}{l}\text { Total transect } \\
\text { length in m (no. } \\
\text { of observers) }\end{array}$ & $\begin{array}{l}\text { Iguanas } \\
\text { seen }\end{array}$ & $\begin{array}{l}\text { Iguanas } \\
\text { per km of } \\
\text { transect }\end{array}$ & $\begin{array}{l}\text { Population } \\
\text { estimate }\end{array}$ \\
\hline 1998 & $993(2)$ & 13 & 13 & $40-80$ \\
2000 & $922(5)$ & 2 & 2 & \\
2003 & $2,327(4)$ & 8 & 3.4 & \\
\hline
\end{tabular}




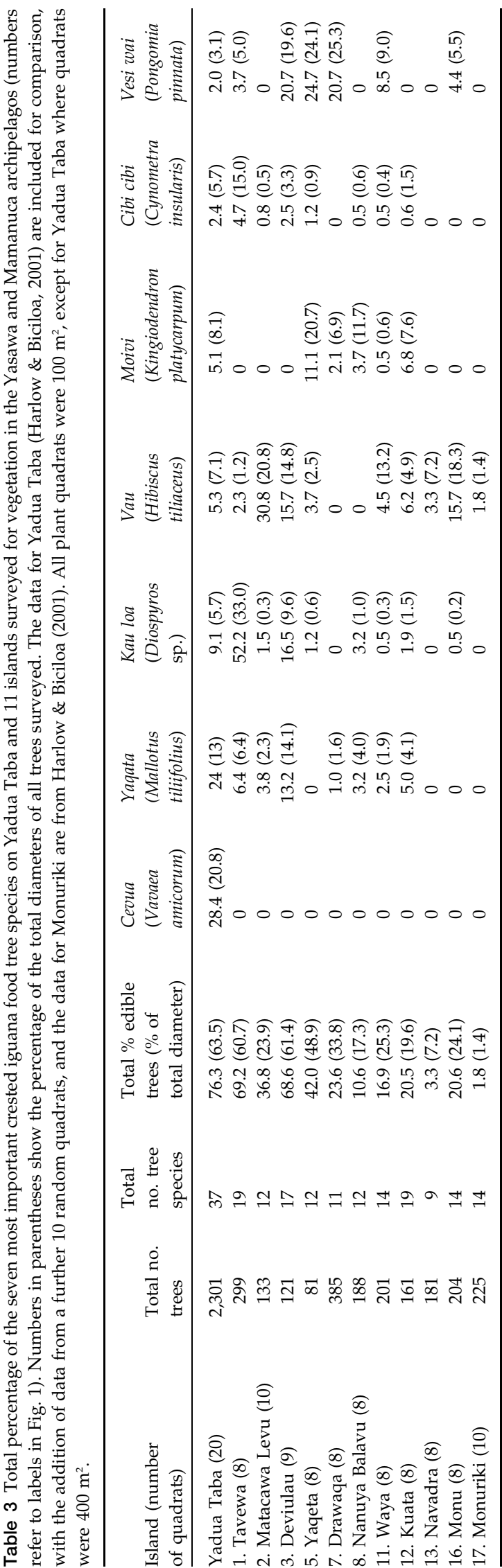

deliberately introduced to Deviulau. The Pacific rat Rattus exulans was detected on four of the five islands where traps were set in September 2000: Deviulau (26 trap nights, 12 rats caught), Matacawa Levu $(52,14)$, Waya $(52,16)$, Nanuya Balavu $(26,10)$ and Vanua Levu $(26,0)$. In July 2003 we also caught $R$. exulans on Monuriki $(30,9)$.

\section{Discussion}

In the absence of information on distribution or abundance, rapid surveys such as ours can contribute important baseline data, identify key areas requiring further work, and stimulate national and international awareness of the plight of a Critically Endangered species such as the Fijian crested iguana. Our surveys found no island with crested iguana densities approaching that of the small crested iguana sanctuary island of Yadua Taba (70 ha), where c. 200 iguanas per hectare live in dry forest habitat (Harlow \& Biciloa, 2001). Even considering that our transects were placed in optimal habitats and were thus biased towards finding iguanas, none of the four islands where we recorded iguanas had population densities greater than c. 2 iguanas per hectare in the best available patch of forest habitat (i.e. along ephemeral watercourses). Mean population densities over the entire forest remnant would be much less.

Factors other than the presence or absence of identified crested iguana food tree species appear to determine the abundance of crested iguanas. Monuriki island, uninhabited and without cats, had the lowest percentage of edible tree species of any island surveyed $(1.8 \%)$ yet crested iguanas were recorded there, although in low numbers. In comparison, the inhabited island of Tavewa had the highest percentage of edible tree species for any island surveyed $(69.2 \%)$, yet no iguanas were found and the inhabitants reported that iguanas have not been seen on the island. Deviulau has a high proportion of iguana food tree species $(68.6 \%)$, yet cats are present and may be responsible for the low numbers of iguanas.

Our recommendations are for the Fiji Government to establish at least one wildlife sanctuary in the Yasawa archipelago (possibly Deviulau) and one in the Mamanuca archipelago (possibly Monuriki or Monu). Although large areas are always preferable to small areas for wildlife reserves, we recommend these small uninhabited islands as possible sanctuaries because (1) goats will never be removed from large islands in Fiji because of their economic importance to the islands' traditional owners, (2) it is difficult and expensive to remove goats, feral cats and invasive plant species from large islands, and (3) under optimal conditions crested 
iguana population densities are high, and even small islands can potentially maintain large populations. Negotiations with the Fijian clans that own the islands of high conservation potential should include discussion about the removal of goats and the end of dry season burning practices. When goats are removed the seedlings of the remaining native plant species will begin to re-establish. Goats preferentially eat the seedlings of more palatable species, which are also the preferred iguana food species (Harlow \& Biciloa, 2001). Alternative sources of income for the Fijian landowners will need to be investigated to replace that lost by removing goats from these islands. Low impact ecotourism is an obvious possibility, and preliminary investigations suggest this should be economically viable, at least in the Mamanuca archipelago (Cebaivalu, 1996).

Crested iguana numbers on all of these islands may already be too low to allow the population to recover unaided. Captive breeding of the remaining individuals (and eventual reintroduction) will have to be considered while the forest habitat is being restored on selected islands. Other possible future options may involve crested iguana translocations from Yadua Taba, or erecting goat exclusion fences on islands that are not subjected to dry season burning (Harlow \& Biciloa, 1999).

A population of at least 80 crested iguanas has recently been found on the 40 ha uninhabited island of Macuata off the northern coast of Fiji's largest island, Viti Levu (Olson \& Keppel, 2004). In 1988 one crested iguana was located on this goat-ravaged island, at which time little forest habitat remained (D. Watling, pers. comm.). In 1994 goats were removed and forest regeneration appears to have been rapid; $60-70 \%$ of the island is now covered in recently regenerated forest, which includes six of the important iguana food tree species we have identified here (Olson \& Farley, 2004).

Currently the only secure population of crested iguanas is the Crested Iguana Sanctuary island of Yadua Taba, administered by the National Trust of Fiji Islands. Dry season burning ceased on Yadua Taba in 1980, the last goat was removed in 2004 , and an invasive plant management programme has recently been implemented (Taylor et al., 2005). A vegetation survey of Yadua Taba and comparison with 1980s aerial photos suggests that $10-20 \%$ of the dry forest has regenerated in the last two decades (Olsen et al., 2002).

With the exception of Yadua Taba, and possibly Macuata Island, crested iguana populations on all other islands will undoubtedly continue to decrease in the absence of immediate action, and will presumably become functionally extinct within the next few years.
Resident Fijians assured us that crested iguanas are still occasionally encountered on four of the five inhabited islands we surveyed, where large dry forest remnants remain (Nacula, Matacawa Levu, Naviti and Waya). These populations cannot be expected to survive in the long-term because of the presence of feral cats and continuing forest degradation due to goat grazing, forest fires and the spread of the invasive vaivai tree. On most of these islands remnant forest patches are separated by large expanses of grassland, probably isolating any remaining crested iguanas in small subpopulations. Most of the smaller inhabited islands in these groups have little or no remaining native forest, and the inhabitants have no living memory of crested iguanas ever being present (e.g. Yanuya, Tavua and Tokoriki).

In November 2004 the IUCN SSC Iguana Specialist Group and the National Trust of Fiji Islands cosponsored a Conservation and Management Plan workshop for Fiji's crested and banded iguanas. The workshop was held at the University of the South Pacific, Suva, and was attended by 50 participants from both within and outside Fiji. The key objectives for conservation of the crested iguana were identified as: prioritization of islands most suitable for long-term survival, field research on iguanas and their habitat requirements, genetic research, development of captive breeding and reintroduction strategies and the establishment of education, awareness and ecotourism programmes. The long-term conservation of the Fijian crested iguana will ultimately depend on having several well protected populations on uninhabited islands free of introduced predators and goats.

\section{Acknowledgements}

Funding for the September 2000 surveys was provided by a BP Conservation Programme Award, and generous support from the Strand family of Los Altos, California, funded the July 2003 surveys. Elizabeth Erasito and the staff at the National Trust of Fiji Islands provided support and encouragement at all times, as did the staff of the Department of Biological Sciences, University of the South Pacific. We thank all the Mataqali involved for giving us permission to visit their islands, and the many Fijians who assisted and helped us along the way. Ingrid Gradinger at Liavata Lodge and Samasoni Nakulawai and his family at Nalauwaki village on Waya provided essential support in 2000, and Sevanaia Nasibi from Yanuya proved to be a skilled boatman and an enthusiastic helper. We gratefully acknowledge the exceptional support given by volunteers Nathalie Apouchtine, Melanie Jeavons and Jamie Orben. 


\section{References}

Bauer, A.M. (1988) A geological basis for some herpetofaunal disjunctions in the southwest Pacific, with special reference to Vanuatu. Herpetological Journal, 1, 259-263.

Brongniart, A. (1800) Essai d'une classification naturelle des reptiles. Bulletin de la Société Philomatique, 2, 89-91.

Buckland, S.T., Anderson, D.R., Burnham, K.P., Laake, J.L., Borchers, D.L. \& Thomas, L. (2001) Introduction to Distance Sampling: Estimating Abundance of Biological Populations. Oxford University Press, Oxford, UK.

Cebaivalu, U. (1996) Monu and Modriki (Monuriki) Islands, Mamanuca Group, Tikina Malolo: Background Information as Basis for an Ecotourist Project. Report by the Landuse Planning Unit, Native Land Trust Board, Suva, Fiji.

Gibbons, J.R.H. (1981) The biogeography of Brachylophus (Iguanidae) including the description of a new species, B. vitiensis, from Fiji. Journal of Herpetology, 15, 255-273.

Gibbons, J.R.H. (1984a) Iguanas of the South Pacific. Oryx, 18, 82-91.

Gibbons, J.R.H. (1984b) Discovery of a brand-new million-yearold iguana. Animal Kingdom, 87, 23-30.

Gibbons, J.R.H. (1985a) The biogeography and evolution of Pacific island reptiles and amphibians. In Biology of Australasian Frogs and Reptiles (eds G. Grigg, R. Shine \& H. Ehmann), pp. 125-143. Surrey Beatty and Sons, Sydney, Australia.

Gibbons, J.R.H. (1985b) On the trail of the crested iguana. Animal Kingdom, 6, 40-45.

Gibbons, J.R.H. \& Watkins, I.F. (1982) Behavior, ecology, and conservation of South Pacific iguanas, Brachylophus, including a newly discovered species. In Iguanas of the World: Their Behavior, Ecology and Conservation (eds G.M. Burghardt \& A.S. Rand), pp. 419-441. Noyes, New Jersey, USA.

Harlow, P.S. \& Biciloa, P.N. (1999) The Population Status of the Crested Iguana (Brachylophus vitensis) on Monuriki Island, Mamanuca Group, Fiji. Unpublished Report. University of Sydney, Sydney, Australia.

Harlow, P.S. \& Biciloa, P.N. (2001) Abundance of the Fijian crested iguana (Brachylophus vitiensis) on two islands. Biological Conservation, 98, 223-231.

IUCN (2006) 2006 IUCN Red List of Threatened Species. IUCN, Gland, Switzerland [http://www.redlist.org, accessed 20 November 2006].
Laurie, W.A., Uryu, H. \& Watling, D. (1987) A faunal survey of Yaduataba Island reserve with particular reference to the crested iguana (Brachylophus vitiensis Gibbons 1981).

Domodomo, 5, 16-28.

Olson, D.M. \& Farley, L. (2004) Fiji's Macuata Island Crested Iguana Conservation Program. Unpublished Report. Wildlife Conservation Society, Suva, Fiji.

Olson, D.M. \& Keppel, G. (2004) Results of a Rapid Survey for the Presence of Fiji's Crested Iguana (Brachylophus fasciatus) on Macuata Island, Vunitogoloa, Ra Province, Viti Levu, Republic of the Fiji Islands. Unpublished Report. Wildlife Conservation Society, Suva, Fiji.

Olson, D.M., Tuiwawa, M.V., Niukula, J., Biciloa, P., Keppel, G., Naikatini, A., Thaman, B. \& Vakausausa, L. (2002) Conservation of Fijian Dry Forest and Fijian Crested Iguanas on Yadua Taba Island. Unpublished Report. Wildlife Conservation Society, Suva, Fiji.

Shea, G.M. (1995) A small collection of skinks and geckos from the Northwestern islands of Fiji (Yasawa and Mamanuca groups). Pacific Science, 49, 126-133.

Taylor, J.E., Harlow, P.S. \& Niukula, J. (2005) Invasive-Plant Assessment and Weed Management Plan for the Fijian Crested Iguana Sanctuary Island of Yadua Taba, Bua. Unpublished Report. National Trust of Fiji Islands, Wildlife Conservation Society \& Zoological Parks Board of NSW, Sydney, Australia. Zug, G. (1991) The Lizards of Fiji: Natural History and Systematics. Bishop Museum Bulletin in Zoology 2, Bishop Museum Press, Honolulu, USA.

\section{Biographical sketches}

All members of the 2000 and 2003 survey terms have broad interests in the natural history of the Fiji Islands including, in particular, reptiles other than iguanas (Peter S. Harlow, Martin Fisher), plants (Marika Tuiwawa, Alifereti Naikatini) and bats (Jorge M. Palmeirim). Peter Harlow is also conducting research on the banded iguana in Fiji. Pita N. Biciloa is the warden of the Yadua Taba crested iguana wildlife sanctuary. 